\title{
Maksimalkan Potensi Geothermal dengan Pembentukan Holding BUMN Geothermal
}

\author{
Jonius Christian Harefa ${ }^{1}$, Udi Harmoko ${ }^{2}$ \\ ${ }^{1}$ Magister Energi, Sekolah Pascasarjana, Universitas Diponegoro; \\ ${ }^{2}$ Departemen Fisika, Fakultas Sains dan Matematika, Universitas Diponegoro;
}

Email :joniuschristian@students.undip.ac.id (J.C.H), udiharmoko@fisika.fsm.undip.ac.id (U.H);

\begin{abstract}
Abstrak : Geothermal merupakan potensi energi yang ramah lingkungan dan merupakan energi primer yang dapat diandalkan dikarenakan siklus pemanfaatannya yang sangat lama. Geothermal energi di Indonesia merupakan cadangan terbesar kedua di dunia. Akan tetapi, pemanfaatannya masih belum maksimal dikarenakan pemanfaatan energi di Indonesia masih di dominasi oleh energi berbahan bakar fosil dibandingkan dengan berbahan bakar non fosil. Transisi pemanfaatan energi dari energi fosil ke non fosil telah dituangkan dalam rencana umum energi nasional. Persentase penggunaan energi terbarukan diharapkan naik setiap tahun, sebaliknya energi fosil perlahan mulai ditinggalkan. Tantangan dalam pemanfaatan geothermal juga sangat besar. Nilai investasi yang sangat besar diawal dan tingkat resiko investasi yang sangat besar membuat investor mengkaji kembali secara matang untuk berinvestasi di sektor ini. Oleh karena itu, pemerintah dalam hal ini melalui kementerian BUMN berencana membentuk Holding BUMN khusus Geothermal energi. Pembentukan Holding BUMN Geothermal diharapkan dapat memaksimalkan potensi "harta karun" Indonesia terbesar kedua di dunia ini. Teknologi geothermal saat ini juga sudah mendukung secara maksimal untuk teknologi combined cycle sehingga pemanfaatannya bisa dimaksimalkan. Holding BUMN merupakan langkah yang tepat untuk pemanfaatan potensi geothermal di Indonesia.
\end{abstract}

Kata Kunci : Geothermal, Holding BUMN, OEC, Energi Terbarukan

\section{Pendahuluan}

Pemerintah Indonesia melalui program 35.000 MW merupakan bentuk komitmen pemerintah dalam menciptakan kemandirian energi dengan memaksimalkan sumber sumber energi terbarukan (Jonan, 2018). Hal ini dilakukan untuk menyelesaikan permasalahan krisis kelistrikan di Indonesia.

Dari gambar 1, dapat dilihat bahwa rasio elektrifikasi Indonesia mengalami kenaikan dari 84,35\% di tahun 2014 kini telah mencapai 99,20\% di tahun 2020. Pada tahun 2021, target rasio elektrifikasi yaitu $99,9 \%$. Daerah yang masih belum mencapai rasio elektrifikasi diantaranya adalah Kalteng dengan $94 \%$, Sultra dengan 94\%, Maluku dengan 92\%, Papua dengan $94 \%$ dan yang paling rendah adalah NTT yang masih $88 \%$ rasio elektrifikasi.

Pada gambar 2 juga menjelaskan penambahan kapasitas pembangkit listrik khususnya energi baru dan terbarukan dalam mendukung program 35.000 MW tersebut. Hal ini diharapkan dapat menurunkan emisi gas rumah kaca yang disebabkan oleh sektor pembangkit listrik, dikarenakan 
Vol. 2, No. 3, pp $144-153$

doi: $10.14710 /$ jebt.2021.11074

pembangkit listrik energi baru dan terbarukan sangat ramah lingkungan dibandingkan dengan pembangkit listrik fosil.

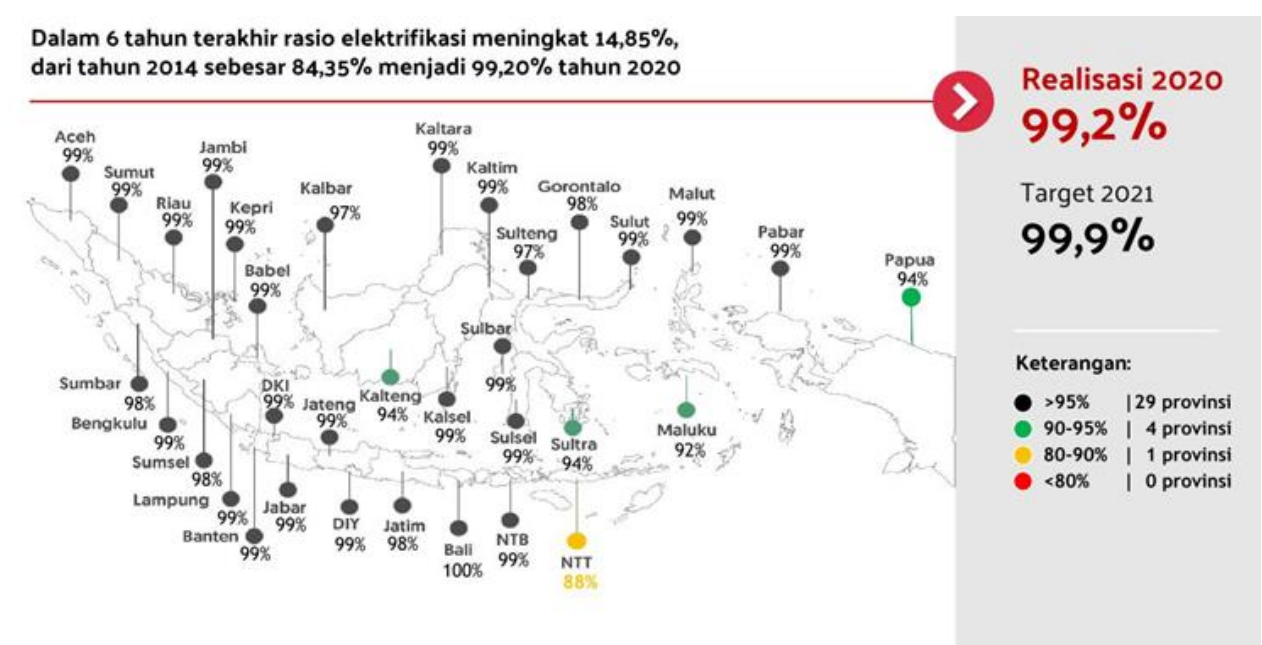

Gambar 1. Rasio Elektrifikasi Indonesia Tahun 2020 (KESDM, 2021)

\section{PEMBANGKIT LISTRIK EBT TERUS MENINGKAT}
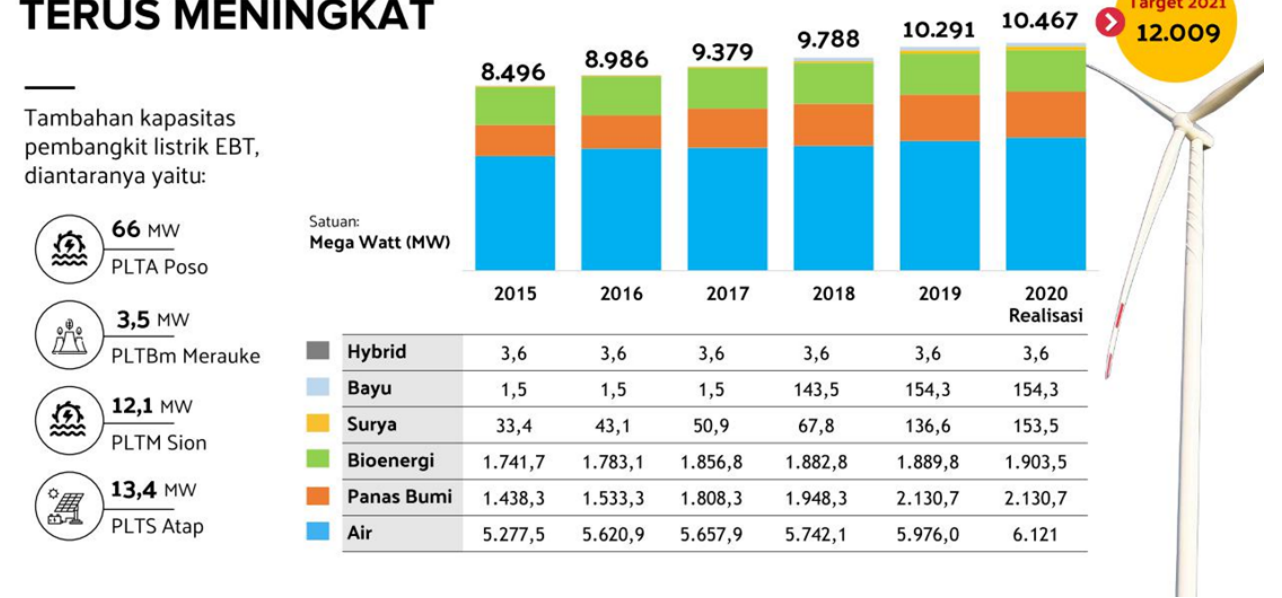

Gambar 2. Kapasitas Pembangkit Listrik EBT (KESDM, 2021)

Pada tahun 2025, target bauran energi dari pembangkit EBT adalah sebesar 23\% (Widodo, 2017). Berbagai usaha telah dilaksanakan untuk memenuhi target tersebut. Pengembangan energi panas bumi merupakan salah satu dari usaha pemenuhan target bauran energi EBT di indonesia. Ditinjau dari pengembangannya yang membutuhkan upaya dan usaha yang besar, kementerian BUMN memulai wacana untuk membuat holding BUMN khusus untuk pengembangan panas bumi. Pembentukan holding BUMN khusus panas bumi ini diharapkan dapat menghadirkan teknologi terbaru dibidang panas bumi. Beberapa teknologi panas bumi dapat menjadi acuan holding BUMN dalam mengembangkan panas bumi. Pada jurnal kali ini akan membahas pentingnya pembentukan holding geothermal dalam pengembangan energi panas bumi serta pengalihan teknologi panas bumi konvensional menjadi pembangkit listrik tenaga panas bumi sistem binary power plant dan pengembangannya menjadi geothermal combined cycle untuk memaksimalkan potensi energi panas bumi yang ada. 
Vol. 2, No. 3, pp $144-153$

doi: $10.14710 /$ jebt.2021.11074

\section{Potensi Panas Bumi}

Pembangkit listrik panas bumi merupakan salah satu dari pembangkit listrik energi terbarukan. Saat ini realisasi penambahan kapasitas pembangkit PLTP yaitu 2,131 MW hingga 2019. Pada gambar 3 menjelaskan perkembangan kapasitas pembangkit PLTP semakin bertambah dari tahun ke tahun. Hal ini membuktikan komitmen pemerintah dalam mendukung transisi sektor energi dari tenaga fosil menjadi non fosil.

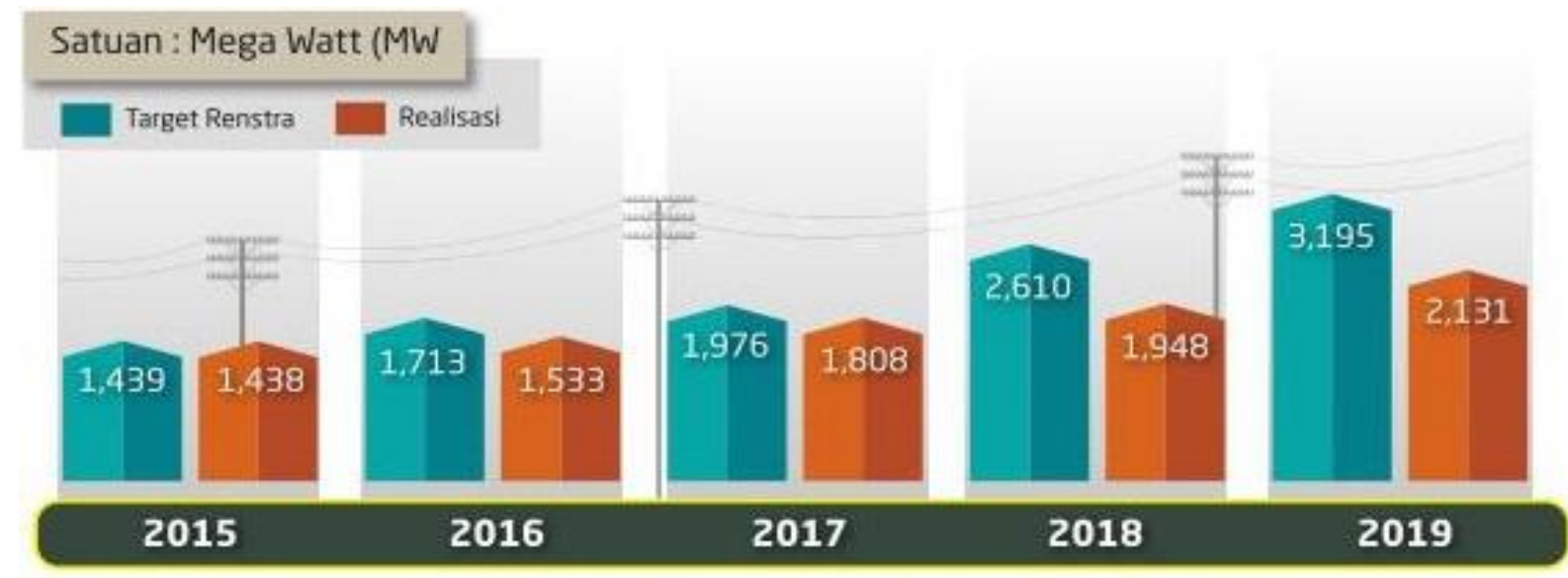

Gambar 3. Perkembangan Kapasitas Terpasang PLTP (KESDM, 2020a)

Proyek PLTP di Indonesia seperti pada gambar 4 dan 5 terbagi menjadi dua wilayah, yaitu wilayah Indonesia bagian barat dan wilayah Indonesia Timur. Potensi terbesar energi panas bumi sebagian besar berada di wilayah Indonesia bagian barat dibandingkan dengan Indonesia bagian timur. Hal ini dikarenakan jalur Cincin Api (Ring of Fire) yang membentang disekitar Pasifik dari tenggara Australia hingga barat daya Amerika (Pambudi, 2018).

Indonesia yang membentang dari Sumatera, Jawa, Bali hingga sebagian kecil di wilayah timur Indonesia memiliki potensi energi panas bumi terbesar dengan potensi sekitar 28 GWe yang terdiri dari 312 lokasi potensi panas bumi (Bina, 2018).

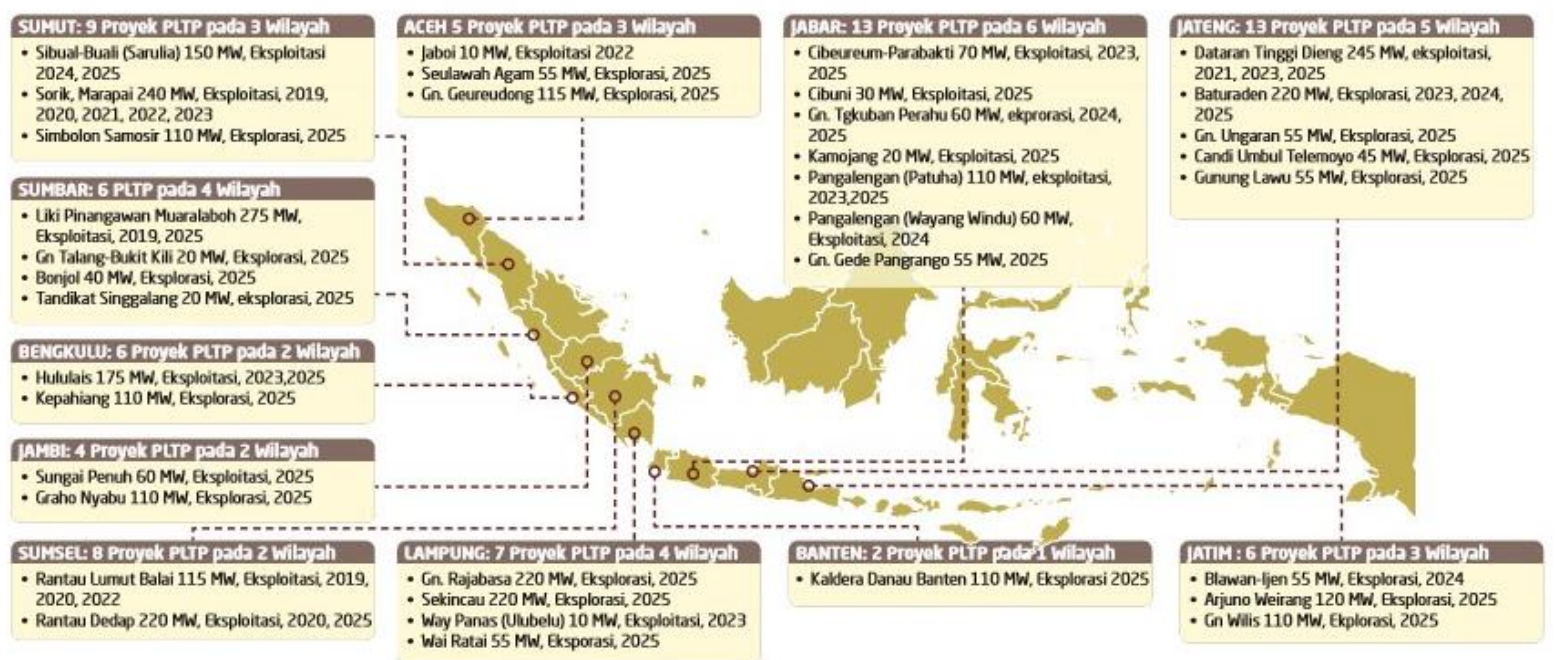

Gambar 4. Proyek PLTP Indonesia Barat (KESDM, 2020b) 


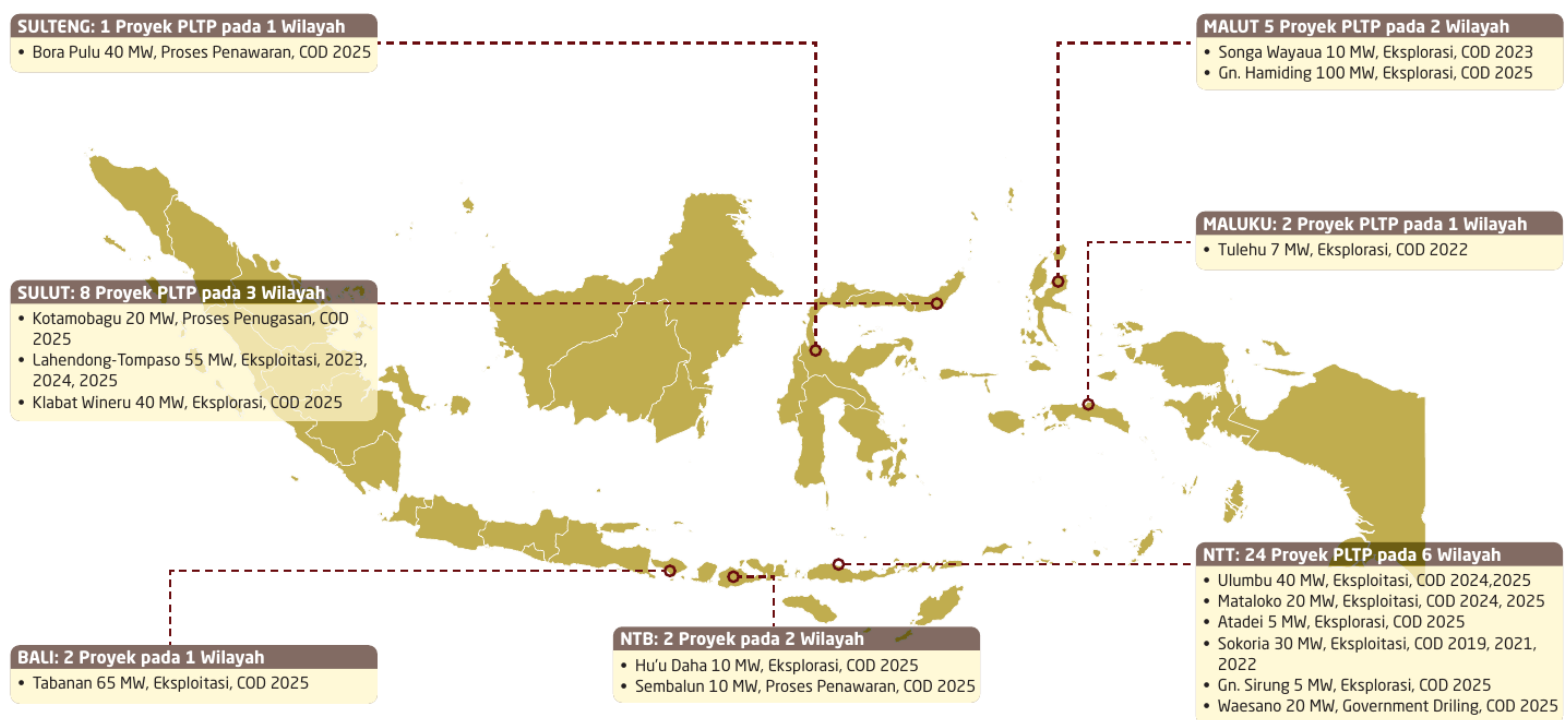

Gambar 5. Proyek PLTP Indonesia Timur (KESDM, 2020b)

Potensi geothermal Indonesia masih banyak yang belum dimaksimalkan. Proyek PLTP diseluruh Indonesia yang masih belum dikelola hingga saat ini berada dalam beberapa tahap awal, sehingga potensi panas bumi masih belum menjadi penyokong utama kelistrikan di Indonesia. Akan tetapi, beberapa proyek panas bumi telah memasuki beberapa tahap akhir, mulai dari eksploitasi hingga commercial operations date (COD). Proyek panas bumi diharapkan dapat sesuai target dan beberapa yang ditargetkan untuk COD pada tahun 2025 dapat tercapai. Panas bumi menjadi salah satu sektor energi terbarukan yang dapat mendukung program kelistrikan di Indonesia. Pemerintah bertujuan untuk meningkatkan bauran energi pemanfaatan energi baru dan terbarukan (EBT) panas bumi dari 9\% menjadi 23\%. Beberapa program yang sedang dilakukan adalah dengan menargetkan lelang 20 wilayah kerja panas bumi pada tahun 2022 hingga 2024 sebagaimana program pengembangan yang dicanangkan pemerintah pada gambar 6.

\section{TUJUAN PROGRAM

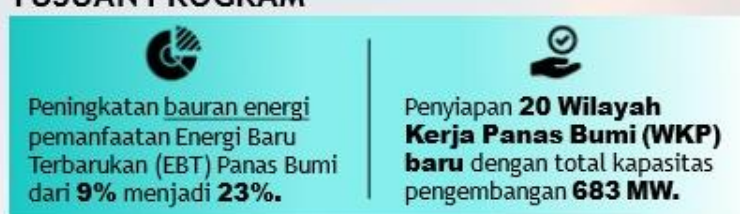 \\ RENCANA KERJA 2020-2022}

\begin{tabular}{|c|c|c|c|c|}
\hline No. & Area Prospek & Status wilayah & $\begin{array}{l}\text { Sumber } \\
\text { Daya }\end{array}$ & $\begin{array}{c}\text { Rencana } \\
\text { Pengembangan }\end{array}$ \\
\hline 1. & Cisolok cisukarame, Jawa Barat & WKP & $45 \mathrm{MW}$ & $20 \mathrm{Mw}$ \\
\hline 2. & Jailolo, Maluku Utara & WKP & $75 \mathrm{MW}$ & $30 \mathrm{Mw}$ \\
\hline 3. & Nage, Nusa Tenggara Timur & WKP & $39 \mathrm{MW}$ & $20 \mathrm{MW}$ \\
\hline 4. & Bittuang, Sulawesi Selatan & Wilayah Terbuka & $28 \mathrm{MW}$ & $20 \mathrm{MW}$ \\
\hline 5. & Ciremai, Jawa Earat & WKP & $60 \mathrm{MW}$ & $55 \mathrm{Mw}$ \\
\hline 6. & Bora Polu, Sulawesi Tengah & WKP & $123 \mathrm{MW}$ & $40 \mathrm{MW}$ \\
\hline 7. & Gunung Endut, Banten & WKP & $180 \mathrm{MW}$ & $40 \mathrm{Mw}$ \\
\hline 8. & Tampomas, Jawa Barat & WKP & $100 \mathrm{MW}$ & $45 \mathrm{MW}$ \\
\hline 9. & Sembalun, Nusa Tenggara Barat & WKP & $100 \mathrm{MW}$ & $20 \mathrm{MW}$ \\
\hline 10. & Guci, Jawa Tengah & WKP & $100 \mathrm{MW}$ & $55 \mathrm{MW}$ \\
\hline 11. & Sipoholon Ria-Ria, sumatera Utara & WKP & $60 \mathrm{MW}$ & $20 \mathrm{MW}$ \\
\hline 12. & Marana, Sulawesi Tengah & WKP & $70 \mathrm{MW}$ & $20 \mathrm{Mw}$ \\
\hline 13. & Lokop, Aceh & Wilayah Terbuka & $41 \mathrm{MW}$ & $20 \mathrm{Mw}$ \\
\hline 14. & Limbong, Sulawesi Selatan & Wilayah Terbuka & $20 \mathrm{MW}$ & $5 \mathrm{MW}$ \\
\hline 15. & Maritaing, Nusa Tenggara Timur & Wilayah Terbuka & $190 \mathrm{MW}$ & $30 \mathrm{Mw}$ \\
\hline 16. & Gunung Batur-Kintamani, Bali & Wilayah Terbuka & $58 \mathrm{MW}$ & $40 \mathrm{Mw}$ \\
\hline 17. & Gunung Galunggung, Jawa Barat & WKP & $289 \mathrm{MW}$ & $110 \mathrm{mw}$ \\
\hline 18. & Papandayan, Jawa Barat & wilayah Terbuka & $195 \mathrm{MW}$ & $40 \mathrm{MW}$ \\
\hline 19. & Banda Baru, Maluku & Wilayah Terbuka & $54 \mathrm{MW}$ & $40 \mathrm{Mw}$ \\
\hline 20. & Sajau, Kalimantan Utara & Wilayah Terbuka & $17 \mathrm{MW}$ & $13 \mathrm{MW}$ \\
\hline \multicolumn{3}{|c|}{ TOTAL } & $1.844 \mathrm{MW}$ & $683 \mathrm{MW}$ \\
\hline
\end{tabular}

Gambar 6. Program Eksplorasi Panas Bumi oleh Pemerintah (KESDM, 2020b) 
Tabel 1.

Sumber dan Cadangan Panas Bumi (KESDM, 2019)

\begin{tabular}{llcccccc}
\hline \multirow{2}{*}{ No. Location } & \multicolumn{2}{c}{ Resources } & \multicolumn{3}{c}{ Reserves } & \multirow{2}{*}{ Total } \\
\cline { 3 - 6 } & & Speculative & Hypothetical & Possible & Probable & Proven n \\
\hline 1 & Sumatera & 2.276 & 1.557 & 3.735 & 1.041 & 1.070 & 9.679 \\
2 & Jawa & 1.265 & 1.190 & 3.414 & 418 & 1.820 & 8.107 \\
3 & Bali & 70 & 21 & 104 & 110 & 30 & 335 \\
4 & Nusa Tenggara & 190 & 148 & 892 & 121 & 12 & 1.363 \\
5 & Kalimantan & 151 & 18 & 13 & 0 & 0 & 182 \\
6 & Sulawesi & 1.365 & 362 & 1.041 & 180 & 120 & 3.068 \\
7 & Maluku & 560 & 91 & 497 & 6 & 2 & 1.156 \\
8 & Papua & 75 & 0 & 0 & 0 & 0 & 75 \\
\hline & Total & 5.952 & 3.387 & 9.696 & 1.876 & 3.054 & 23.965 \\
\hline
\end{tabular}

Pada Tabel 1 menunjukkan cadangan panas bumi Indonesia sangatlah besar. Potensi panas bumi ini tersebar dari Sumatera hingga Papua. Hal ini dikarenakan Indonesia berada di Ring of Fire sehingga hampir seluruh wilayah di Indonesia memiliki potensi panas bumi. Akan tetapi, menurut (Ragimun, 2013) investasi di sektor energi panas bumi relatif rumit dan sangat besar terutama untuk biaya eksplorasi dan eksploitasi. Banyak kendala dan hambatan dalam mengembangkan energi terbarukan.

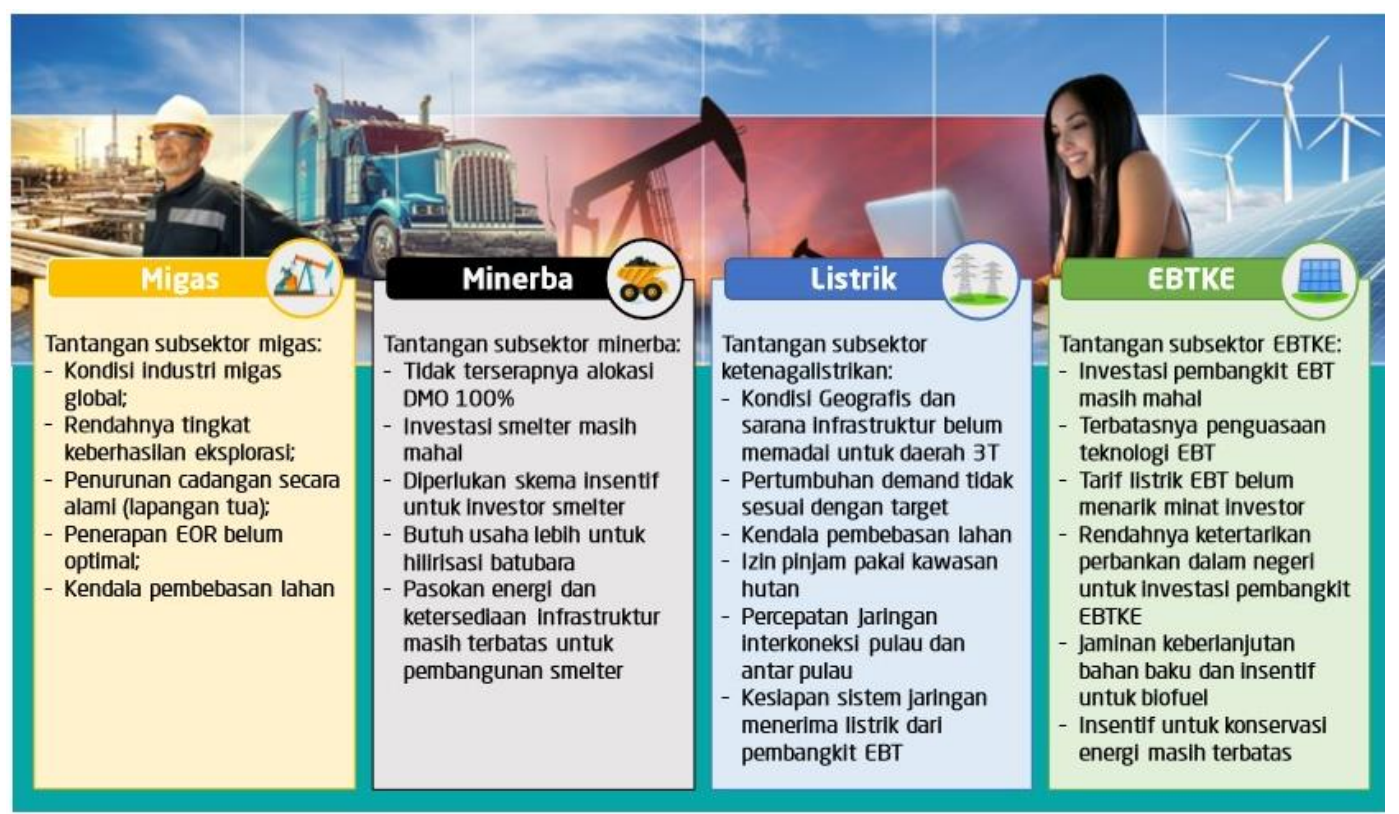

Gambar 7. Tantangan Sektor ESDM (KESDM, 2020b)

Pada gambar 7 menunjukkan bahwa investasi pembangkit untuk sektor energi baru dan terbarukan masih tergolong mahal. Tantangan berikutnya dalam pengembangan EBT yaitu masih terbatasnya penguasaan teknologi EBT di Indonesia. Untuk mencapai sasaran pengembangan PLTP di Indonesia, beberapa kegiatan telah ditingkatkan oleh kementerian terkait khususnya panas bumi, yaitu : 
1) Menugaskan BUMN/BLU untuk mengembangkan PLTP

2) Mengalokasikan pembiayaan pengembangan panas bumi melalui PMN dan pinjaman kepada BUMN.

3) Meningkatkan kualitas dan kuantitas survei potensi sumber daya dan cadangan panas bumi.

4) Melakukan pelelangan Wilayah Kerja (WK) panas bumi minimal 7 WK per tahun

5) Menyiapkan rekomendasi WK panas bumi minimal 4 WK per tahun

6) Memberikan penugasan survei pendahuluan dan/atau eksplorasi kepada Badan Usaha

7) Menyusun kebijakan harga jual listrik panas bumi

8) Meningkatkan survei pendahuluan dan/atau eksplorasi oleh instansi pemerintah

Kementerian BUMN yang berada dibawah kepemimpinan Menteri BUMN Erick Thohir memberikan gagasan tentang pembentukan holding BUMN panas bumi (Dwi Afriyadi, 2021). Hal ini dapat mempercepat pengembangan panas bumi di Indonesia dikarenakan terbentuknya finansial yang kuat. Finansial holding BUMN panas bumi yang semakin besar dan kuat diharapkan juga dapat meningkatkan penguasaan teknologi EBT khususnya di sektor panas bumi. Teknologi pengembangan panas bumi sekarang sudah mulai baik, ditandai dengan mulainya penerapan teknologi combined cycle di pembangkit listrik tenaga panas bumi di Indonesia.

\section{Holding BUMN Panas Bumi}

Tahun 2021, rencana pembentukan holding BUMN kembali disampaikan oleh menteri BUMN. Rencana ini untuk memberikan penguatan pada korporasi pemerintah untuk mendukung program kelistrikan di Indonesia. Pertamina Geothermal Energy, PT. Geo Dipa Energy, PT. PLN Gas dan Geothermal merupakan perusahaan milik pemerintah yang dikabarkan masuk dalam rencana pembentukan holding BUMN tersebut (Umah, 2021).

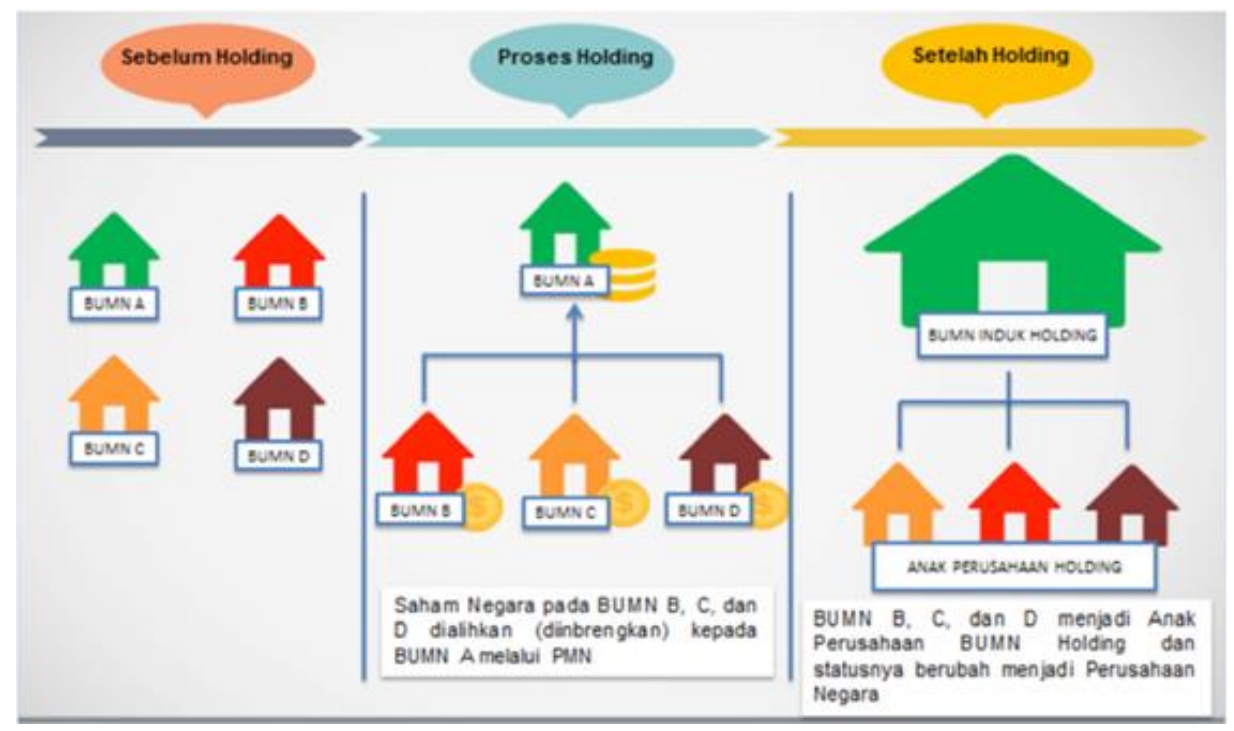

Gambar 8. Proses pembentukan Holding BUMN (Usman, 2018)

Pada pembentukan holding BUMN tersebut juga didukung landasan hukum yang kuat. Terutama UU nomor 17 tahun 2003 tentang keuangan negara dan juga UU nomor 19 tahun 2003 tentang badan usaha milik negara. Sehingga rencana pembentukan ini sangat mungkin terjadi dan dapat menghadirkan energi masa depan Indonesia terutama energi panas bumi. 


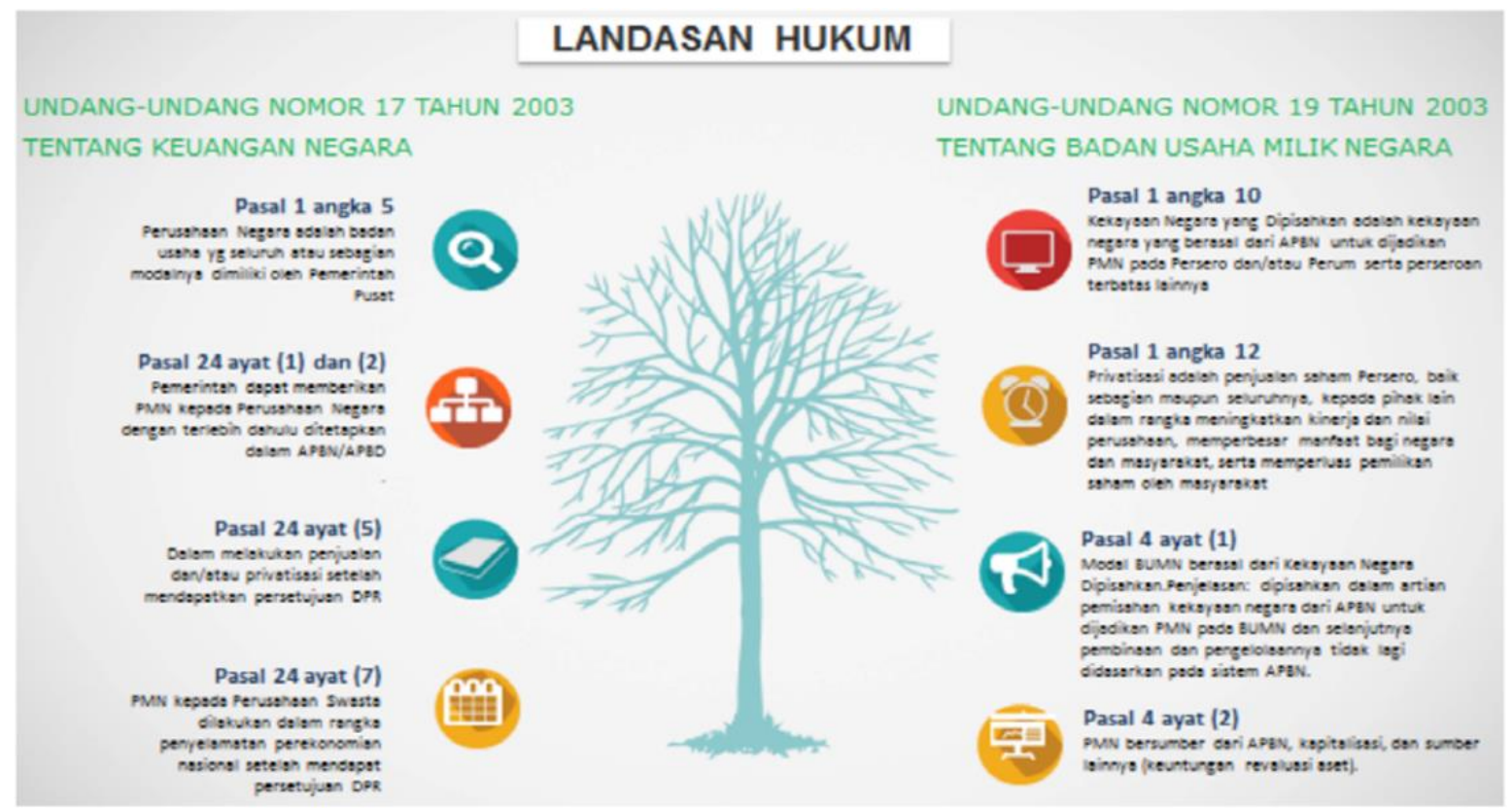

Gambar 9. Landasan Hukum Holding BUMN (Usman, 2018)

Menurut Dedi Syarif Usman selaku Direktur Kekayaan Negara Dipisahkan menyatakan bahwa pembentukan holding company merupakan salah satu strategi dasar dalam BUMN melalui pengelompokkan beberapa BUMN ke dalam satu perusahaan induk (Holding), dimana BUMN yang menjadi anggota holding akan menjadi anak perusahaan dari holding company (Usman, 2018). Adapun tujuan pembentukan holding company adalah sebagai berikut :

1) Mencapai ukuran (size) perusahaan yang secara keuangan (financially) lebih kuat.

2) Meningkatkan daya saing dan posisi tawar perusahaan

3) Mencapai economies of scale melalui peningkatan efisiensi dan efektivitas usaha

4) Menciptakan sinergi antara anggota holding

5) Meningkatkan kemampuan pendanaan dan memperbaiki struktur permodalan.

Dengan terbentuknya holding, diharapkan kedepannya akan terbentuk BUMN yang:

1) Efisien dan produktif, berdaya saing nasional, regional, dan global

2) Berkontribusi yang optimal kepada pemerintah dan stakeholders

3) Taat dalam penerapan tata kelola perusahaan yang baik

4) Berorientasi pada penciptaan nilai tambah yang tinggi, skala ekonomis, usaha yang terfokus dan terintegrasi dengan core competencies yang jelas.

Pembentukan holding BUMN Panas Bumi akan terjadi perubahan dan harapannya dengan terjadi penguatan secara keuangan dan disertai dengan orientasi kepada penciptaan nilai tambah yang tinggi maka holding panas bumi dapat menjadi menghadirkan nilai tambah dalam sektor panas bumi dengan memanfaatkan kemajuan dibidang teknologi panas bumi. Teknologi terbaru di sektor panas bumi saat ini adalah teknologi binary. Teknologi ini merubah PLTP konvensional menjadi Combined Cycle dengan memanfaatkan kembali energi panas sisa keluaran dari steam turbine generator konvensional. Teknologi geothermal combined cycle merupakan teknologi terbaru di Indonesia. Dengan terbentuknya holding BUMN di sektor panas bumi harapannya mampu menghadirkan teknologi combined cycle di PLTP konvensional yang sudah beroperasi di Indonesia saat ini. 
Vol. 2, No. 3, pp $144-153$

doi: $10.14710 /$ jebt.2021.11074

\section{Teknologi Geothermal Combined Cycle}

Geothermal combined cycle sudah banyak diterapkan di seluruh dunia. Akan tetapi, di Indonesia masih belum banyak yang menggunakan teknologi tersebut. Satu satunya geothermal combined cycle di Indonesia adalah Sarulla Operation Limited. Teknologi ini memanfaatkan kembali uap sisa dan brine (air panas) untuk menghasilkan listrik kembali sebelum akhirnya di masukkan kembali kedalam bumi. Teknologi PLTP combined cycle Sarulla merupakan teknologi PLTP combined cycle pertama di Indonesia.

\begin{tabular}{|c|c|c|c|c|c|c|}
\hline $\begin{array}{l}\text { BROAD POLICY } \\
\text { GOALS }\end{array}$ & $\begin{array}{l}\text { EFFECTIVENESS } \\
\text { INDICATOR }\end{array}$ & SARULLA & ULUBEIU $3 \& 4$ & $\begin{array}{l}\text { LAHENDONG } \\
5 \& 6\end{array}$ & PATUHA & $\begin{array}{l}\text { WAYANG } \\
\text { WINDU } 2\end{array}$ \\
\hline $\begin{array}{l}\text { Increase private } \\
\text { sector participation }\end{array}$ & $\begin{array}{c}\text { Private finance in } \\
\text { development }\end{array}$ & $\begin{array}{l}53 \% \text { public debt } \\
20 \% \text { private debt } \\
27 \% \text { private equity } \\
\text { Pre-completion } \\
\text { revenue }\end{array}$ & $\begin{array}{l}57 \% \text { public debt } \\
43 \% \text { public equity }\end{array}$ & $\begin{array}{l}45 \% \text { public debt } \\
55 \% \text { public equity }\end{array}$ & $\begin{array}{l}63 \% \text { public debt } \\
37 \% \text { public equity }\end{array}$ & $\begin{array}{l}\text { All private } \\
\text { finance }\end{array}$ \\
\hline \multirow{3}{*}{$\begin{array}{l}\text { Meet electricity } \\
\text { demand through } \\
\text { rapid deployment } \\
\text { and low cost }\end{array}$} & $\begin{array}{l}\text { Time to } \\
\text { deployment from } \\
\text { financial close } \\
\text { (expected) }\end{array}$ & $30-48$ months & $23-33$ months & $22-28$ months & 49 months & 20 months \\
\hline & Cost & USD $5.0 \mathrm{~m} / \mathrm{MW}$ & USD $2.9 \mathrm{~m} / \mathrm{MW}$ & USD $4.8 \mathrm{~m} / \mathrm{MW}$ & USD $2.9 \mathrm{~m} / \mathrm{MW}$ & USD1.8m/MW \\
\hline & Technology & Combined Cycle & Single Flash & Single Flash & Dry Steam & Single Flash \\
\hline \multirow{2}{*}{$\begin{array}{l}\text { Deploy renewable } \\
\text { energy to achieve } \\
\text { energy sovereignty }\end{array}$} & MW Installed & $330 \mathrm{MW}$ & $110 \mathrm{MW}$ & $20 \mathrm{MW}$ & $55 \mathrm{MW}$ & $117 \mathrm{MW}$ \\
\hline & $\begin{array}{c}\text { Year of } \\
\text { Commissioning } \\
\text { (expected) }\end{array}$ & $2016-2018$ & 2017 & 2017 & 2014 & 2009 \\
\hline
\end{tabular}

Gambar 10. Teknologi geothermal di Indonesia (Rakhmadi, 2015)

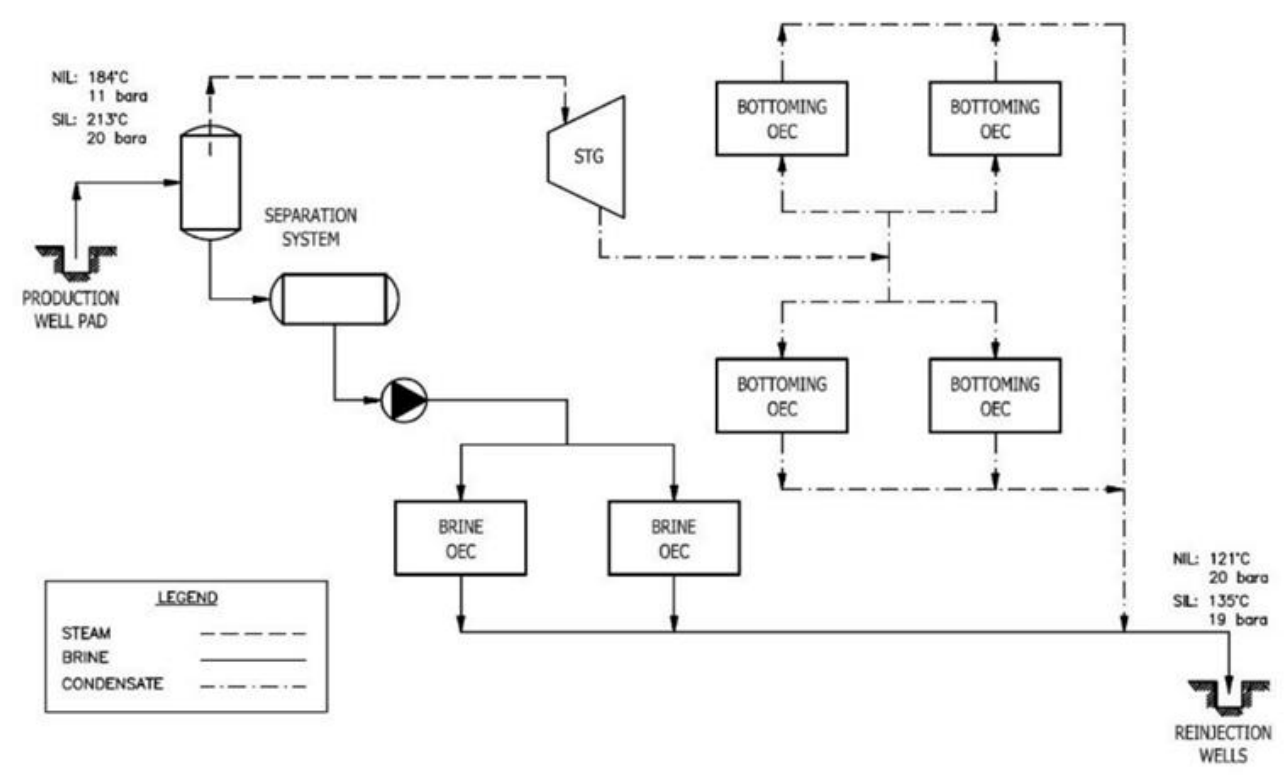

Gambar 11. Bottoming OEC dan Brine OEC (Wolf, 2015)

Pada gambar 11 menjelaskan pemanfaatan sumber panas bumi untuk geothermal combined cycle. Teknologi OEC (Ormat Energy Converter) menggunakan uap sisa dan brine (Hot Water) untuk digunakan kembali menghasilkan listrik dengan generator berkapasitas kecil sebelum akhirnya di injeksi kembali ke dalam bumi. Teknologi tersebut merupakan teknologi binary dengan sistem Organic Rankine Cycle (ORC) yaitu dengan menggunakan fluida kedua sebagai fluida kerja. Menurut (Sorgulu, 
2021) sebuah ORC diintegrasikan ke dalam sistem untuk menghasilkan listrik dengan cara yang efisien. Menggunakan cairan organik sebagai pengganti air yang merupakan teknologi yang menjanjikan. Teknologi binary sangat sesuai dengan panas bumi di Indonesia dikarenakan energi panas bumi di Indonesia banyak yang memiliki suhu dibawah $170^{\circ} \mathrm{C}$ dan dengan suhu uap yang fluktuatif keluaran dari sumur (Nasrudin, 2020).

\section{Kesimpulan}

Penguatan korporasi melalui holding BUMN geothermal merupakan langkah awal yang sangat baik dalam menyambut bauran green energy di Indonesia. Harapannya dengan penguatan khususnya dalam finansial dapat menghadirkan geothermal yang lebih baik dan efisien lagi baik dari segi pemanfaatan sumber energinya hingga penerapan teknologi terbaru, sehingga potensi yang ada dapat benar benar dimaksimalkan.

Teknologi binary dapat menjadi teknologi yang dapat dipertimbangkan setelah terbentuknya holding BUMN panas bumi. PLTP Sarulla yang telah berhasil menjadi PLTP combined cycle pertama di Indonesia dapat menjadi harapan pengembangan panas bumi di Indonesia menjadi lebih baik dari segi memaksimalkan pemanfaatan sumber energi panas bumi.

\section{Daftar Pustaka}

Bina, S. M. (2018). Classification of Geothermal Resources in Indonesia by Applying Exergy Concept. Renewable and Sustainable Energy Reviews.

Dwi Afriyadi, A. (2021). Erick Thohir Mau Bikin Holding Panas Bumi, Kapan? Detik.Com. https://finance.detik.com/energi/d-5475828/erick-thohir-mau-bikin-holding-panas-bumi-kapan

Jonan, I. (2018). Rencana Usaha Penyediaan Tenaga Listrik PT PLN Persero. Kementerian ESDM.

KESDM. (2019). Kementrian ESDM, Handbook of Energy \& Economic Statistics of Indonesia 2019.

KESDM. (2020a). Rencana Strategis Kementerian Energi dan Sumber Daya Mineral 2020-2024.

KESDM. (2020b). Ringkasan RENSTRA 2020-2024.

KESDM. (2021). Capaian Kinerja 2020 \& Program 2021. www.esdm.go.id

Nasrudin, N. (2020). Exergy, Exergoeconomic, and Exergoenvironmental Optimization of the Geothermal Binary Cycle Power Plant at Ampallas, West Sulawesi, Indonesia. Thermal Science and Engineering Progress.

Pambudi, N. A. (2018). Geothermal Power Generation in Indonesia, a Country within the Ring of Fire: Current Status, Future Development and Policy. Renewable and Sustainable Energy Reviews.

Ragimun. (2013). Revitalisasi Investasi Pengembangan Energi Panas Bumi Di Indonesia. Kajian Ekonomi Dan Keuangan, 17(Maret), 1-24.

Rakhmadi, R. (2015). Using Private Finance to Accelerate Geothermal Deployment: Sarulla Geothermal Power Plant, Indonesia. Climate Policy Initiative, June, 30. http://climatepolicyinitiative.org/publication/using-private-finance-to-accelerate-geothermaldeployment-sarulla-geothermal-power-plant-indonesia/

Sorgulu, F. (2021). A New Experimentally Developed Integrated Organic Rankine Cycle Plant. Applied Thermal Engineering. 
Vol. 2, No. 3, pp $144-153$

doi: $10.14710 /$ jebt.2021.11074

Umah, A. (2021). Akan Jadi Bagian Holding BUMN Panas Bumi, Ini Proyek Geo Dipa. CNBC Indonesia. https://www.cnbcindonesia.com/news/20210225171139-4-226198/akan-jadi-bagian-holdingbumn-panas-bumi-ini-proyek-geo-dipa

Usman, D. S. (2018). Holding BUMN Untuk Kesejahteraan Rakyat. 28. www.djkn.kemenkeu.go.id

Widodo, J. (2017). Rencana Umum Energi Nasional. KEMENKUMHAM.

Wolf, N. (2015). Sarulla 330 MW geothermal project key success factors in development. Transactions - Geothermal Resources Council, 39, 907-912 